\title{
Impulse Testing of Power Cables-Simulation Cum Experimental Approach
}

\author{
Arunjothi. R \\ Central Power Research Institute \\ Bangalore, India
}

\author{
Thirumurthy, Meena K P \\ Central Power Research Institute, India \\ Bangalore, India
}

\begin{abstract}
The capability to withstand the lightning transients is a mandatory requirement for any high voltage equipment, especially power cable system. As a type test, this test is carried out on the cable system of about 20 to 25 metres length of cable mounted with all accessories and at the applicable Basic Impulse Level voltage (BIL) of that system. Generally, the selection of number of stages, rise time resistors, tail resistors etc to get the required Lightning Impulse wave shape within the tolerance limit is achieved by trial and error method. When the test is carried out at higher voltages this process of changing resistors will become a tedious process. Hence, an effort is made to simulate the Impulse Generator in MATLAB Simulink, which will help to decide the number of stages, and proper resistor values according to the sample capacitance and test voltage. The test results from the simulation are compared with the experimental test results of the impulse generator for various power cable systems. The results of the Impulse simulation and experimental work are observed to be within $\pm 5 \%$ variation. Hence the simulation of the circuit of Impulse Generator is helpful to arrive at the resistance values and number of stages to be used for the testing of a particular cable system.
\end{abstract}

Keywords—Lightning Impulse; Power Cable System;

\section{INTRODUCTION}

Electrical Insulation Systems are prone to experience overvoltage transients from lightning strikes and they should withstand such a severe sudden overvoltage conditions caused by lightning. High-Voltage Impulse Testing is performed to assess the ability of Electrical Insulation Systems to withstand such high-voltage impulses. High Voltage Impulse testing is part of type test for electrical equipment like transformers, motors, coils, Power cables, switches, circuit breakers, surge protection devices and individual insulation materials. The type test simulates the real stresses of the cable system reasonably and checks the performance and lifetime operation of the cable system.

Unlike other products, Impulse test on Power cable systems are generally carried out at an elevated conductor temperature of 95 to $100^{\circ} \mathrm{C}$. The sample should withstand ten positive and ten negative impulse shots at elevated conductor temperature. For cable systems, before applying the impulse voltage, the cable is heated by passing suitable current through the cable to raise the conductor temperature to a temperature between 95 to $100{ }^{\circ} \mathrm{C}$. After 2 hours of reaching the stabilized conductor temperature, the sample will be subjected to 10 positive and 10 negative impulse voltage applications.

\section{IMPULSE GENERATOR}

The rated capacity of the Impulse Generator in the laboratory is $2400 \mathrm{kV}$ and $240 \mathrm{~kJ}$. There are 24 stages in the impulse generator with maximum charging voltage of $100 \mathrm{kV}$ per stage. In each stage, two charging capacitors of rating $4 \mu \mathrm{F}$ are connected in series. The capacitors in the connected stages are charged in parallel to a voltage $\mathrm{V}$ relative to ground. When the bottom sphere gap is triggered by voltage injection, discharging of the stage capacitors happens in series through the resistors, cumulatively raising the voltage to $\mathrm{nV}$, where $\mathrm{n}$ is the number of stages and $\mathrm{V}$ is the charging voltage per stage. The actual voltage is measured through the $2400 \mathrm{kV} \mathrm{RC}$ high voltage divider of 1750 Ratio.

The basic impulse levels (BIL) of different voltage rating of the Power cables are given in Table I. The basic lightning impulse wave shape is defined by $1.2 / 50 \mu \mathrm{s} .1 .2$ micro second refers to the front time of an impulse wave, which is the time taken by the wave to reach to its maximum value starting from zero value. Since it is difficult to identify the start and peak points of the lightning impulse the front time is specified as $(1 / 0.6)$ times $\left(t_{2}-t_{1}\right)$, where $t_{2}$ is the time for the wave to reach to its $90 \%$ of the peak value and $t_{1}$ is the time to reach $30 \%$ of the peak value. Since $\left(t_{2}-t_{1}\right)$ represents about $60 \%$ of the front time, it is multiplied by (1/0.6) to give front time of the lightning impulse [1]. Similarly 50 micro second refers to the tail time, which is the time between peak values to $50 \%$ of peak [2].

TABLE I. BASIC IMPULSE VOLTAGE OF CABLES OF VARIOUS

\begin{tabular}{|c|c|}
\hline \multicolumn{2}{|c|}{ RATINGS } \\
\hline $\begin{array}{c}\text { Cable Rated voltage, } \mathbf{k V} \\
\text { (RMS) }\end{array}$ & $\begin{array}{c}\text { Impulse Test Voltages, } \mathbf{k V} \\
\text { (Peak) }\end{array}$ \\
\hline $6.35 / 11$ & 75 or 95 \\
\hline $8.7 / 15$ & 95 or 112 \\
\hline $11 / 11$ & 95 \\
\hline $12 / 20$ & 125 \\
\hline $12.7 / 22$ & 125 or 144 \\
\hline $18 / 30$ & 170 \\
\hline $19 / 33$ & 170 or 194 \\
\hline $26 / 45$ & 250 \\
\hline $38 / 66$ & 325 \\
\hline $66 / 132$ & 550 \\
\hline $127 / 220$ & 1050 \\
\hline & \\
\hline
\end{tabular}

\section{IMPULSE TESTING OF POWER CABLE SYSTEMS} UNDER NO LOAD

Simulation of Impulse generator is carried out by MATLAB Simulink. The impulse parameters of the same experimental condition were also simulated in MATLAB by incorporating the $350 \mathrm{pF}$ divider. Along with divider internal damping 
resistance of $360 \Omega$ and external damping resistor of $250 \Omega$ are also connected in the test circuit.

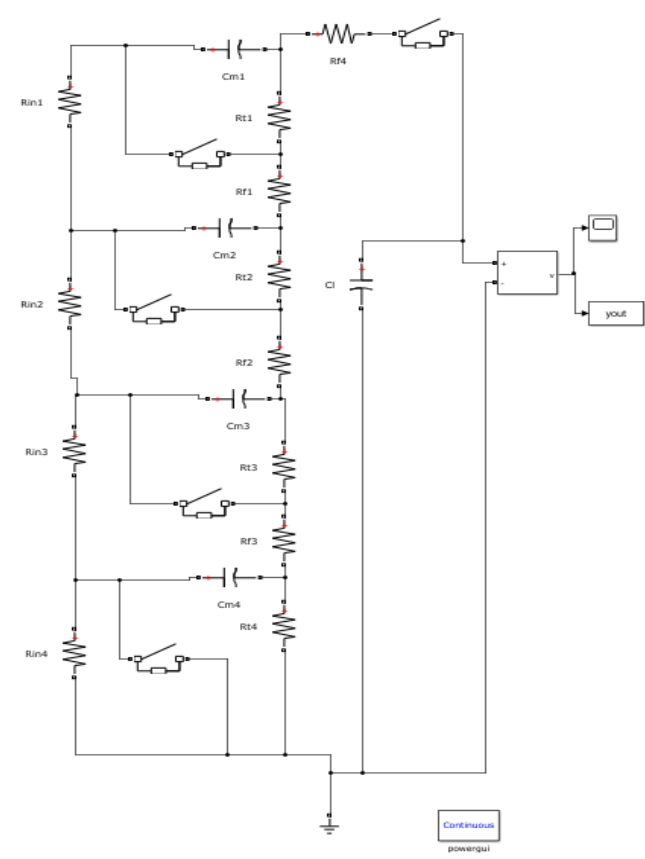

Fig. 1. Four stage Impulse Generator simulation in Simulink

Impulse voltage generator is developed in MATLAB Simulink with standard blocks available in Simulink. The twenty four stage impulse voltage generator is simulated with the software. The sphere gaps of the stages were simulated by the use of switches [3]. And each of the stage capacitors was assigned an initial charge voltage value, which is equal to the actual charging voltage applied per stage during the actual test. The values of front and tail resistors, as well as the stage capacitors, are the same as used in the actual impulse generator. The simulation circuit considered for 24 stages is a expanded version of the four stage simulation shown in Figure 1.

A small program is written in MATLAB which automatically derives the $t_{1}$ and $t_{2}$ values from the simulated lightning impulse and calculates the front time of the simulated impulse. In this simulation circuit the equivalent capacitance of each stage capacitors is considered in the circuit. The laboratory and simulation results of voltage test are as given in Table II and Table III.

TABLE II. PEAK VOLTAGE OF IMPULSE WAVEFORM BY EXPERIMENTAL AND SIMULATION AT NO LOAD

\begin{tabular}{|c|c|c|c|c|c|c|}
\hline $\begin{array}{c}\text { No of } \\
\text { stage } \\
\text { of the } \\
\text { genera } \\
\text { tor }\end{array}$ & \multicolumn{2}{|c|}{$\begin{array}{c}\text { Charging } \\
\text { Voltage Per } \\
\text { stage (kV) }\end{array}$} & \multicolumn{2}{|c|}{ Peak Voltage (kV) } & \multicolumn{2}{|c|}{$\begin{array}{c}\text { Efficiency of the } \\
\text { Impulse } \\
\text { Generator (\%) }\end{array}$} \\
\cline { 2 - 7 } & $\begin{array}{c}\text { Simula } \\
\text { tion }\end{array}$ & $\begin{array}{c}\text { Experi } \\
\text { ment }\end{array}$ & $\begin{array}{c}\text { Simulati } \\
\text { on }\end{array}$ & $\begin{array}{c}\text { Experim } \\
\text { ent }\end{array}$ & $\begin{array}{c}\text { Simula } \\
\text { tion }\end{array}$ & $\begin{array}{c}\text { Experi } \\
\text { ment }\end{array}$ \\
\hline 24 & -100 & -100 & -1829 & -2276 & 76.2 & 94.4 \\
\hline 24 & +90 & +90 & 1653 & 2016 & 76.5 & 92.8 \\
\hline
\end{tabular}

TABLE III. FRONT \& TAIL TIME OF IMPULSE WAVEFORM BY EXPERIMENTAL AND SIMULATION AT NO LOAD

\begin{tabular}{|c|c|c|c|c|}
\hline \multirow{2}{*}{$\begin{array}{c}\text { No of } \\
\text { stages of } \\
\text { the } \\
\text { generator }\end{array}$} & \multicolumn{2}{|c|}{ Front Time $(\boldsymbol{\mu S})$} & \multicolumn{2}{c|}{ Tail Time $(\boldsymbol{\mu S})$} \\
\cline { 2 - 5 } & $\begin{array}{c}\text { Simula } \\
\text { tion }\end{array}$ & $\begin{array}{c}\text { Experimen } \\
\mathbf{t}\end{array}$ & $\begin{array}{c}\text { Simulatio } \\
\mathbf{n}\end{array}$ & $\begin{array}{c}\text { Experimen } \\
\mathbf{t}\end{array}$ \\
\hline 24 & 1.15 & 1.2 & 49.58 & 50 \\
\hline
\end{tabular}

From the Table II and III, it is evident that the front time and tail time parameters are exactly matching for both experiment and simulation. The time parameters are same for both positive and negative polarities in the case simulation and as well as experiment. However the peak voltage and efficiency of the generator of both the cases are not matching in no load condition.

In this simulation circuit, each stage consists of one resultant charging capacitor, however in the actual impulse generator two capacitors are connected in series and each stage capacitors are connected through potential resistors $\left(R_{\text {pot }}\right)$ as shown in Figure 2. Since the simulation model of Figure 1 is not exactly reflecting the actual impulse generator, the simulation circuit was modified to include potential resistors connected between stages through the two series charging capacitors. The modified four stage equivalent simulation circuit is as given below in Figure 2.

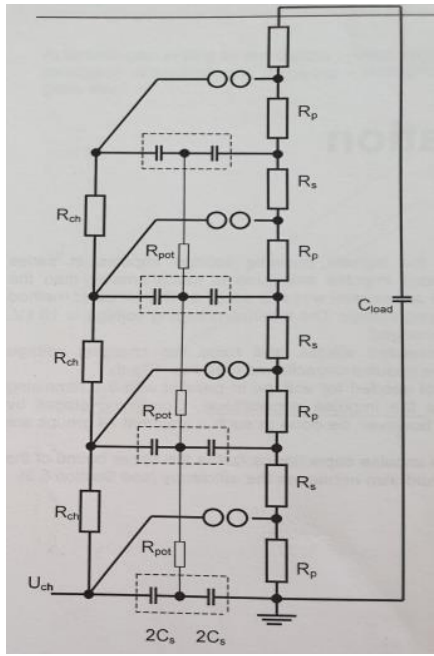

Fig. 2. Modified Four stage equivalent simulation circuit in Simulink

Now the impulse voltage test was conducted using the modified 24 stage simulation circuit to check with the results of experimental work. In this case, each series capacitor of the stage is assigned half of the charging voltage. Table IV shows the peak voltage \& efficiency obtained from simulation and experiment work.

TABLE IV. PEAK VOLTAGE OF IMPULSE WAVEFORM BY EXPERIMENTAL AND MODIFIED SIMULATION AT NO LOAD

\begin{tabular}{|c|c|c|c|c|c|c|}
\hline $\begin{array}{c}\text { No of } \\
\text { stages } \\
\text { of the } \\
\text { genera } \\
\text { tor }\end{array}$ & \multicolumn{2}{|c|}{$\begin{array}{c}\text { Charging Voltage } \\
\text { Per stage (kV) }\end{array}$} & \multicolumn{2}{|c|}{ Peak Voltage (kV) } & \multicolumn{2}{|c|}{$\begin{array}{c}\text { Efficiency of the } \\
\text { Impulse } \\
\text { Generator (\%) }\end{array}$} \\
\cline { 2 - 7 } & $\begin{array}{c}\text { Simul } \\
\text { ation }\end{array}$ & $\begin{array}{c}\text { Experi } \\
\text { ment }\end{array}$ & $\begin{array}{c}\text { Simula } \\
\text { tion }\end{array}$ & $\begin{array}{c}\text { Experi } \\
\text { ment }\end{array}$ & $\begin{array}{c}\text { Simula } \\
\text { tion }\end{array}$ & $\begin{array}{c}\text { Experi } \\
\text { ment }\end{array}$ \\
\hline 24 & -100 & -100 & -2311 & -2276 & 96.3 & 94.4 \\
\hline 24 & +90 & +90 & 2080 & 2016 & 96.3 & 92.8 \\
\hline 24 & -50 & -50 & -1155 & -1109 & 96.3 & 92.4 \\
\hline 24 & +50 & +50 & 1155 & 1133 & 96.3 & 94.4 \\
\hline
\end{tabular}


Here the numbers of stages used are 24 and the results from both positive and negative polarity results are correlated. Similarly, Table V shows the front and tail time parameters of simulated and experimental work. The time parameters are same for positive and negative polarities. They are also not changing with respect to the charging voltage. Figure 3 shows the Lightning Impulse curve of the simulation.

TABLE V. FRONT \& TAIL TIME OF IMPULSE WAVEFORM BY EXPERIMENTAL AND MODIFIED SIMULATION AT NO LOAD

\begin{tabular}{|c|c|c|c|c|}
\hline \multirow{2}{*}{$\begin{array}{c}\text { No of } \\
\text { stages of } \\
\text { the } \\
\text { generator }\end{array}$} & \multicolumn{2}{|c|}{ Front Time $(\mu S)$} & \multicolumn{2}{c|}{ Tail Time $(\mu S)$} \\
\cline { 2 - 5 } & Simulation & Experiment & $\begin{array}{c}\text { Simulatio } \\
\mathrm{n}\end{array}$ & $\begin{array}{c}\text { Experim } \\
\text { ent }\end{array}$ \\
\hline 24 & 1.27 & 1.2 & 49.23 & 50 \\
\hline
\end{tabular}

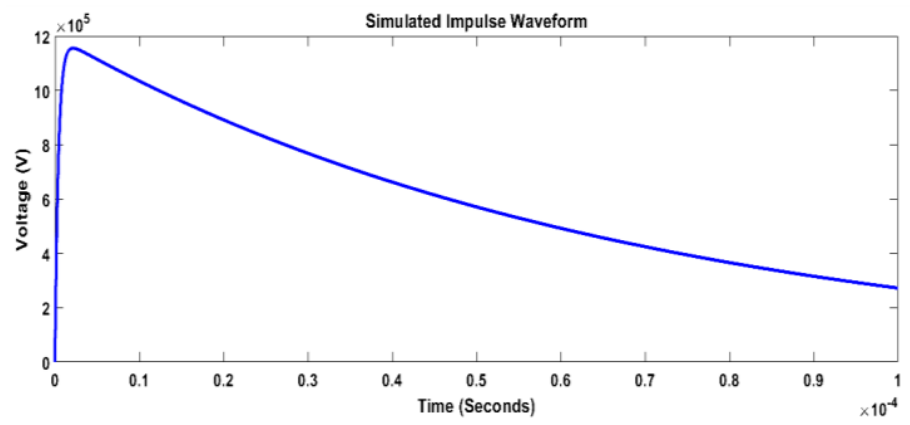

Fig, 3. Simulated Lightning Impulse Waveform

\section{IMPULSE TESTING OF POWER CABLE SYSTEMS UNDER LOAD}

The various cables and cable systems of different voltage ratings are subjected for lightning impulse test and the number of stages are being selected as per the impulse voltage levels from 4 to 19

The details of Cable systems tested, the total capacitance of the cable systems and the number stages used for lightning impulse testing are as given below in Table VI. Figure 4 shows the mounting arrangement of the $220 \mathrm{kV}$ Cable system for lightning impulse test.

The simulation circuit as per figure 2 is built in MATLAB Simulink considering the cable as a capacitive load and the actual measured capacitance of each cable is used in the simulation circuit [4] [5]. In this simulation circuit with test object load, the results observed in both the simulation and experiments are given in the tables VII and VIII.

TABLE VI. PEAK VOLTAGE OF IMPULSE WAVEFORM BY EXPERIMENTAL AND SIMULATION AT LOAD WITH MODIFIED SIMULATION

\begin{tabular}{|l|l|l|l|}
\hline $\begin{array}{l}\text { SI.N } \\
\text { o }\end{array}$ & Particulars of Cable & $\begin{array}{l}\text { Capacitance } \\
(\mathbf{n F})\end{array}$ & $\begin{array}{l}\text { No of } \\
\text { stages } \\
\text { used }\end{array}$ \\
\hline 1 & $\begin{array}{l}\text { 3C X 400 sq.mm 19/33 kV } \\
\text { XLPE insulated Cable with } \\
\text { accessories }\end{array}$ & 4 \\
\hline 2 & $\begin{array}{l}\text { 1X 630 Sq.mm, 64/110 kV } \\
\text { XLPE insulated Cable with } \\
\text { accessories }\end{array}$ & 10 \\
\hline
\end{tabular}

\begin{tabular}{|l|l|l|l|}
\hline 3 & $\begin{array}{l}\text { 1C X 1200 Sq.mm, XLPE } \\
\text { Insulated 127/220 kV Cable } \\
\text { with accessories }\end{array}$ & 4.450 \\
\hline 4 & $\begin{array}{l}\text { 1CX1200 Sq.mm, XLPE } \\
\text { Insulated, 127/ 220 kV Cable } \\
\text { with accessories }\end{array}$ & 4.213 & 19 \\
\hline 5 & $\begin{array}{l}\text { 1C X 2000 Sq.mm, XLPE } \\
\text { Insulated, 127/ 220 kV Cable } \\
\text { with accessories }\end{array}$ & 19 \\
\hline 6 & $\begin{array}{l}\text { IC X 300 Sq.mm, XLPE } \\
\text { Insulated, 76/132 kV Cable } \\
\text { with accessories }\end{array}$ & 11 \\
\hline
\end{tabular}

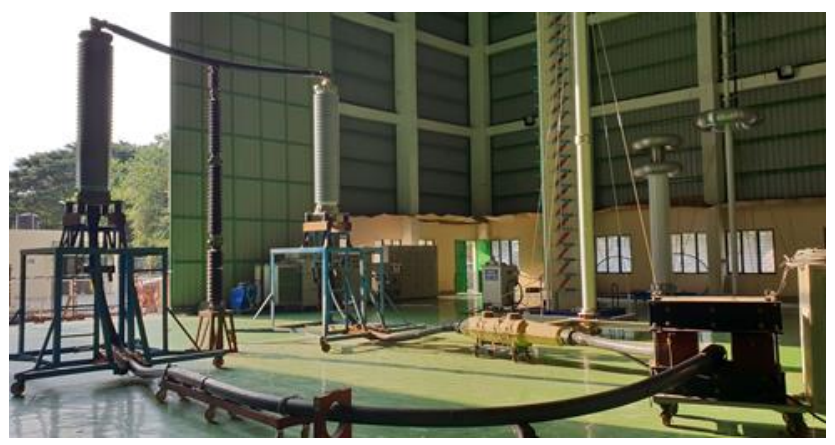

Fig.4. Impulse test set up of a $220 \mathrm{kV}$ XLPE Cable System

The peak voltage, front time and tail time observed with different combinations of stages for cables by simulation and as well as experimental are given in the Tables VII and VIII.

TABLE VII. PEAK VOLTAGE OF IMPULSE WAVEFORM BY EXPERIMENTAL AND SIMULATION WITH LOAD

\begin{tabular}{|c|c|c|c|c|c|c|}
\hline $\begin{array}{c}\text { No of } \\
\text { stages } \\
\text { of the } \\
\text { genera } \\
\text { tor }\end{array}$ & \multicolumn{2}{|c|}{$\begin{array}{c}\text { Charging Voltage } \\
\text { Per stage (kV) }\end{array}$} & \multicolumn{2}{|c|}{ Peak Voltage (kV) } & \multicolumn{2}{|c|}{$\begin{array}{c}\text { Efficiency of the } \\
\text { Impulse } \\
\text { Generator (\%) }\end{array}$} \\
\cline { 2 - 7 } & $\begin{array}{c}\text { Simula } \\
\text { tion }\end{array}$ & $\begin{array}{c}\text { Experi } \\
\text { ment }\end{array}$ & $\begin{array}{c}\text { Simulat } \\
\text { ion }\end{array}$ & $\begin{array}{c}\text { Experi } \\
\text { ment }\end{array}$ & $\begin{array}{c}\text { Simulat } \\
\text { ion }\end{array}$ & $\begin{array}{c}\text { Experi } \\
\text { ment }\end{array}$ \\
\hline 4 & 44.5 & 42.7 & 169.5 & 170.6 & 95.5 & 99.6 \\
\hline 10 & 58.5 & 55.5 & 543 & 545 & 92.8 & 98.2 \\
\hline 19 & 61 & 58.2 & 1046 & 1050 & 90.3 & 95.0 \\
\hline 19 & 60.5 & 57.9 & 1050 & 1050 & 91.3 & 95.5 \\
\hline 19 & 61.5 & 58.0 & 1046 & 1048 & 89.5 & 95.0 \\
\hline 11 & 63 & 58.8 & 651 & 650 & 93.9 & 99.5 \\
\hline
\end{tabular}

From Table VII, it is observed that the peak voltage and the efficiency obtained in the simulation is always 3.5 to 5.5 percent lesser than the actual impulse voltage achieved in the laboratory. Table VIII shows the front time and tail time of the impulse waveform obtained through experimental method and simulation.

TABLE VIII. FRONT \& TAIL TIME OF IMPULSE WAVEFORM BY EXPERIMENTAL AND SIMULATION WITH LOAD

\begin{tabular}{|c|c|c|c|c|}
\hline \multirow{2}{*}{$\begin{array}{c}\text { No of stages } \\
\text { of the } \\
\text { generator }\end{array}$} & \multicolumn{2}{|c|}{ Front Time $(\boldsymbol{\mu S})$} & \multicolumn{2}{c|}{ Tail Time $(\boldsymbol{\mu S})$} \\
\cline { 2 - 5 } & $\begin{array}{c}\text { Simulati } \\
\text { on }\end{array}$ & $\begin{array}{c}\text { Experime } \\
\text { nt }\end{array}$ & Simulation & Experiment \\
\hline 4 & 1.55 & 1.58 & 46.91 & 45.37 \\
\hline 10 & 2.20 & 1.91 & 49.39 & 48.79 \\
\hline 19 & 2.59 & 2.42 & 52.53 & 51.32 \\
\hline 19 & 2.17 & 2.26 & 53.27 & 51.13 \\
\hline 19 & 2.70 & 2.57 & 53.43 & 51.53 \\
\hline 11 & 1.82 & 1.94 & 48.85 & 48.50 \\
\hline
\end{tabular}


From Table VIII, it is evident that the time parameters of simulation and experimental work are very much comparable. Figure.5 shows the simulated negative polarity lightning impulse of $650 \mathrm{kV}$ peak using 11 stages of simulation. Figure 6 shows the experimental waveform of $1048 \mathrm{kV}$ peak voltage obtained using 19 stages of impulse generator.

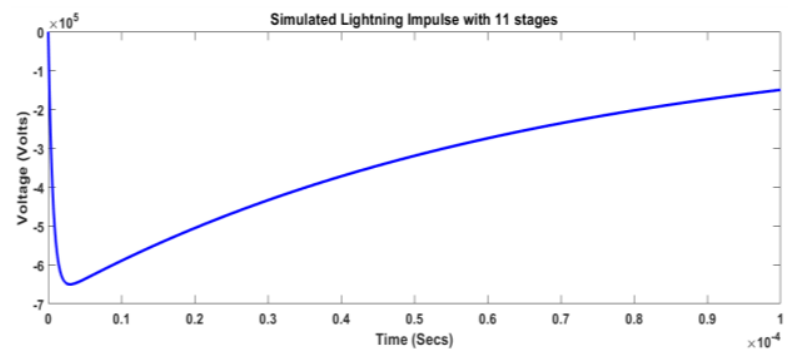

Fig. 5. Simulated Lightning Impulse Waveform of negative polarity

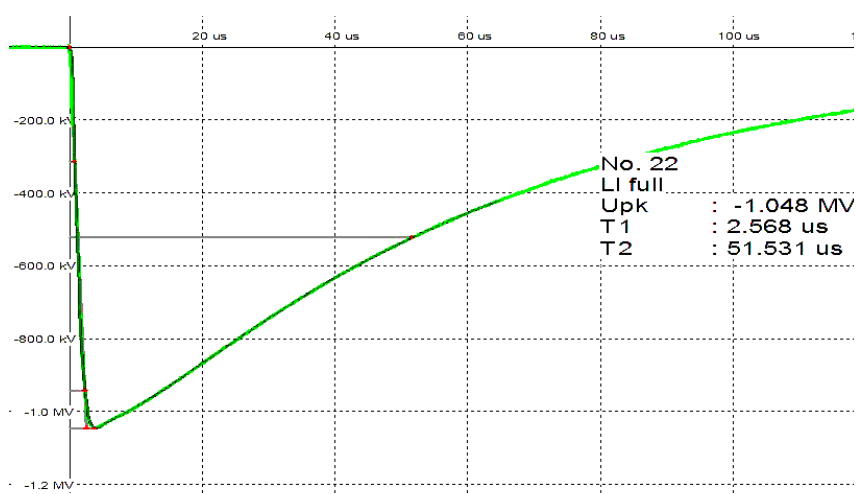

Fig.6. Experimental Lightning Impulse Waveform of negative polarity

\section{CONCLUSION}

Both actual Impulse Generator and Simulated Impulse Generator have almost similar output, validating the MATLAB model both in no load condition and with load of test samples of various capacitances. The minor variations may be due to change in capacitance at elevated temperature and the effect of stray capacitances. This simulated model can be used to fix the tail and rise time resistors and number of stages for actual testing. The comparison was done for various cable samples of different capacitances and voltage rating. From the comparable results of experiment and simulation, it can be concluded that if the sample capacitance is known the number of stages and the value of front and tail resistors can be chosen from the simulation for the desired wave shape. By this way, the time and manpower can be utilized optimally to achieve the desired wave shape without subjecting the test sample for trial test.

\section{ACKNOWLEDGMENT}

The authors would like to thank the management of Central Power Research Institute for giving opportunity to publish this technical paper

\section{REFERENCES}

[1] IEC: 60060-1-2010-09; High Voltage Test Techniques Part-I: General Definitions And Test Requirements

[2] Lavkesh Patidar, Hemant Sawarkar, "Impulse Testing of Power Transformers For Effective Resistors Using Orcad Pspice", International Journal Of Scientific Research And Education, Volume 2, Issue 9 pp.1977-1983, September-2014

[3] Muhammad Saufi Kamarudin, Erwan Sulaiman, Md Zarafi Ahmad, Shamsul Aizam Zulkifli and Ainul Faiza Othman, "Impulse Generator and Lightning Characteristics Simulation using Orcad PSpice Software", Proceedings of EnCon2008 2nd Engineering Conference on Sustainable Engineering Infrastructures Development \& Management, December- 2008

[4] Ashvini Kumar, Ranjana Singh, "Simulation of Impulse Voltage Generator with Capacitive Load of Bushing in Matlab/Simulink", IJSRD - International Journal for Scientific Research \& Development| Vol. 4, Issue 02, 2016

[5] Ashvini Kumar, Ranjana Singh, "Simulation of Impulse Voltage Generator in different Impulse Voltages for Testing of Underground Power Cables in MATLAB/SIMULINK", Global Journal of Engineering Science and Reasearches, April 2016. 